Discussion Paper No. 10-029

Social Return on Investment of Mutual Support Based Housing Projects:

Potential for Socio-Economic Cost Savings and Higher Living Quality

Sarah Borgloh and Peter Westerheide

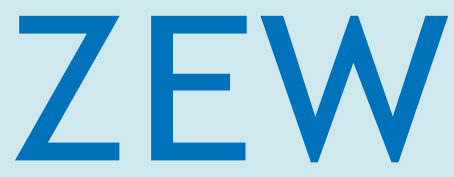

Zentrum für Europäische Wirtschaftsforschung $\mathrm{GmbH}$

Centre for European

Economic Research 
Discussion Paper No. 10-029

\section{Social Return on Investment of Mutual Support Based Housing Projects: \\ Potential for Socio-Economic Cost Savings and Higher Living Quality}

Sarah Borgloh and Peter Westerheide

Download this ZEW Discussion Paper from our ftp server:

ftp://ftp.zew.de/pub/zew-docs/dp/dp10029.pdf

Die Discussion Papers dienen einer möglichst schnellen Verbreitung von neueren Forschungsarbeiten des ZEW. Die Beiträge liegen in alleiniger Verantwortung der Autoren und stellen nicht notwendigerweise die Meinung des ZEW dar.

Discussion Papers are intended to make results of ZEW research promptly available to other economists in order to encourage discussion and suggestions for revisions. The authors are solely responsible for the contents which do not necessarily represent the opinion of the ZEW. 


\section{Non-Technical Summary}

The aging of populations in the demographic change in many industrialized countries will lead to increasing costs of professional support and care for frail elderly. In order to lower the resulting financial burden for the social security system, reforms are necessary. New housing projects which foster mutual support among neighbors might contribute to solve this problem in the future. By decreasing the need for professional care and help such housing projects could lead to lower costs for the support of frail elderly.

Our paper describes the results of a Social Return on Investment (SROI) analysis of four housing projects in Germany. Their common feature is the promotion of mutual neighborly assistance and joint activities among neighbors, which are coordinated and encouraged by social workers. Moreover, elder residents' daily life is facilitated by infrastructural characteristics, among these accessibility, common meeting rooms and open contact space.

Our analysis is based on a survey among residents and is complemented by a businesslevel analysis. This approach enables us to collect data on the residents' need for assistance, on how this assistance is provided, and on community life within the projects. Furthermore, we gather information on costs and yields resulting from the housing projects. To identify the effects of living in one of the projects, we compare our results to a control group of individuals living in conventional settings. We apply the method of propensity score-matching to determine differences in the need for care, the patterns of care provision, as well as cost differentials between the two groups.

Our results point to substantial socio-economic cost savings induced the living conditions in the new housing projects. The costs for supporting elderly are lower than in conventional settings, which is partly due to better health conditions of the residents. These differences may to some extent be ascribed to mutual support by neighbors which is explicitly encouraged in these housing projects. Moreover, residents seem to be more active and rate living conditions more positively. As residents and the social insurance system currently seem to profit most from these cost savings, it would be important to compensate the non-profit-organizations which run the housing projects for the additional expenses incurred for promoting and facilitating mutual neighborly assistance. 


\section{Das Wichtigste in Kürze}

Der mit dem demographischen Wandel wachsende Anteil älterer Menschen in vielen Industrieländern wird $\mathrm{zu}$ steigenden Kosten für die professionelle Unterstützung und Pflege hilfebedürftiger Älterer führen. Um die daraus resultierenden finanziellen Belastungen für das soziale Sicherungssystem zu begrenzen, sind Reformen notwendig. Einen möglichen Beitrag könnten neue Formen des Wohnens im Alter leisten, in denen unentgeltliche gegenseitige nachbarschaftliche Hilfe gefördert wird. Wenn sich damit der Bedarf an professioneller Hilfe verringert, dann könnten die sozialen Kosten für Unterstützungs- und Pflegeleistungen gesenkt werden.

Unser Beitrag beschreibt die Ergebnisse einer Social Return on Investment (SROI)Analyse von vier alternativen Wohnprojekten in Deutschland. Diese Projekte fördern die gegenseitige nachbarschaftliche Unterstützung und gemeinsame Aktivitäten, u.a. durch Besonderheiten ihrer baulichen Infrastruktur (Barrierefreiheit, Gemeinschaftsräume, Kontaktflächen), und den flankierenden Einsatz von Sozialarbeitern.

Unsere Studie basiert auf einer Befragung der Bewohner dieser Wohnprojekte und wird durch eine betriebswirtschaftliche Analyse ergänzt. Diese Vorgehensweise liefert sowohl Daten zur Ausprägung und Deckung des Unterstützungsbedarfs der Bewohner und zum Zusammenleben in den Modellprojekten als auch Informationen über die Kosten und Erträge der Projekte. Um die Auswirkungen der Projekte zu analysieren, nehmen wir einen Vergleich der Ergebnisse mit einer Kontrollgruppe vor. Diese besteht aus Individuen, die in herkömmlichen Wohnformen (Altersheim, betreutes Wohnen, eigener Haushalt) leben. Wir verwenden die Methodik des Propensity Score-Matchings, um Unterschiede in Bedarf und Erbringung von Unterstützungsleistungen sowie Kostenunterschiede zwischen diesen beiden Gruppen zu ermitteln.

Unsere Ergebnisse deuten auf substanzielle sozioökonomische Kostensenkungspotenziale in den Modellprojekten hin. Die Unterstützungskosten für ältere Bewohner sind signifikant niedriger als in herkömmlichen Wohnformen, was zum Teil auf einen besseren Gesundheitszustand der Bewohner zurückgeführt werden kann. Diese Kostenunterschiede 
resultieren $\mathrm{zu}$ einem gewissen $\mathrm{Ma} \beta$ aus nachbarschaftlicher Hilfe, die in den Modellprojekten explizit angeregt wird. Darüber hinaus scheinen die Bewohner der Modellprojekte ein aktiveres Leben $\mathrm{zu}$ führen und bewerten ihre Lebensbedingungen positiver. Da die Kosteneinsparungen derzeit im Wesentlichen den Bewohnern und den Sozialversicherungen zugute kommen, erscheint eine Kompensierung der Mehraufwendungen auf der Trägerebene angezeigt. 


\title{
Social Return on Investment of Mutual Support Based Housing Projects: Potential for Socio-Economic Cost Savings and Higher Living Quality
}

\author{
Sarah Borgloh and Peter Westerheide• \\ Centre for European Economic Research (ZEW), Mannheim
}

May 2010

\begin{abstract}
Our paper describes the results of a Social Return on Investment analysis of four new housing projects in Germany. A common characteristic of all projects is the central importance of mutual neighborly support to meet the demand for the assistance of older residents. All projects share some common architectural features and infrastructural characteristics. Furthermore, in each housing project, some form of support by social workers takes place. Using a propensity score matching approach, we compare for the first time systematically the costs for support of older people in mutual support based housing projects with a control group of people living in conventional settings. Our results, based on a sample of more than 700 residents, point not only to improvements in living satisfaction, but indicate also a huge potential for socio-economic cost savings. This can partly be explained by better development of residents' health status.
\end{abstract}

Keywords: Senior Housing; Cohousing; Mutual support; Assisted Living; Long term care

JEL-Classification: J14, R31, I10

- Corresponding Author: Peter Westerheide, Centre for European Economic Research (ZEW Mannheim), e-mail: westerheide@zew.de; phone: +49 (0) 621-1235-146, fax: +49 (0) 6211235-223. P.O. Box 103443, 68034 Mannheim, Germany. 


\section{Introduction}

The demographic change will lead to increasing costs of professional support and care for frail elderly. To prevent excessive burdens for the social insurance system and social welfare institutions, reforms in the social security system are indispensable. New housing projects that foster subsidiary mutual support among neighbors might pave the road to lower costs for care and support and decreased dependency on professional care and support. A potential for cost savings would legitimate higher investments in new housing projects and to that end a measuring instrument for the return of social projects is necessary.

Our paper describes the results of a Social Return on Investment (SROI) analysis of four new housing projects in Germany. ${ }^{1}$ Each of the projects was developed and is yet run by a major German non-profit organization. The housing projects are very heterogeneous with respect to the age composition and number of their residents, some institutional characteristics and their location in rural versus urban settings. However, a common characteristic of all projects is the central importance of mutual neighborly assistance as well as coordination and encouragement by social workers. Besides that, all projects share some common architectural features and infrastructural characteristics (accessibility for handicapped individuals, availability of common meeting rooms and open contact space like access balconies, atriums, open backyards and gardens).

We compare - to our knowledge for the first time systematically, based on an econometric analysis of survey data of more than 700 residents - the costs for support and care for elderly people in these settings with a control group of people living in conventional settings (either independently in their own household, in conventional assisted housing for elderly or in old peoples' homes/nursing homes). Our analysis proves that the potential of mutual support based housing projects is not limited to improvements of life and housing

1 The analysis was carried out by the authors in cooperation with Gunnar Lang, ZEW, on behalf of the Center for Social Investment (CSI) at the University of Heidelberg. The surveys were conducted by Weeber \& Partner, Tübingen. We highly appreciate helpful comments by the committee of SONG innovation managers and the SONG steering committee. 
satisfaction, but that these projects are able to induce substantial socio-economic cost savings as well.

In the following we first give a short review of the literature (section 2), briefly describe the housing projects we are focusing on (section 3), discuss our research methods (section 4) and describe our results (section 5). Section 6 summarizes our findings in a short conclusion.

\section{Literature review}

Contributions related to our subject come from different disciplines and directions. A rather broad literature discusses the housing preferences of older people in general. A more focused strand of literature analyses infrastructural conditions that foster mutual support, and describes the development and the character of supportive relationships between neighbors. Finally, a further group of papers provides some evidence on experiences in senior cohousing projects, "Continuing Care Retirement Communities" and "Aging in Place" projects that resemble in some respect the new projects in the focus of our study. These prior contributions concentrate on qualitative aspects of life in mutual support housing projects without explicitly considering costs and returns - which is the focus of our study.

Concerning housing preferences, a number of papers from environmental psychology state that older people wish to live independently as long as possible (Christensen et al., 1992 and sources quoted there). Physical housing conditions (maintenance status) tend to become less important particularly for the oldest old people. Old people, particularly home-owners, prefer to stay in their familiar environment and therefore also tend to overconsume housing because they do frequently not adapt their housing demand to their shrinking household sizes (Clark and Deurloo, 2006).

Mutual support relationships among acquainted persons or friends are more likely to emerge in an environment with frequent (daily) contact and geographical proximity (Barker, 2002; Dono et al., 1979; O’Bryant, 1985). Barker (2002, p. 161) particularly 
highlights the imminent role of socializing activities and frequent contact: "Aside from introductions through neighbors, friends, or family participation in voluntary organizations such as churches, an important mechanism for establishing these relationships were mundane, ordinary activities or chance encounters. Usually, care giving arrangements did not arise between complete strangers, although connections before care giving were often rather tenuous, for example, confined to exchanging greetings or pleasantries with neighbors. When needs changed, however, these acquaintances were recast and became mobilized in new ways."

In many respects close to the housing projects in our study are senior cohousing projects, as they may be found particularly in Denmark, Sweden (Choi, 2004) and the Netherlands (Glass, 2009 and the sources cited there). Descriptive analyses of these projects show high levels of satisfaction with the housing situation and overall life quality, not at least due to a high frequency of informal contact with other residents. Social contact is promoted by a similar layout of dwellings that attributes much weight to joint facilities, common greens etc. Involvement of future residents in the planning process is supportive to the well-being of residents, as well as is easy access to professional care services, particularly for the older residents. According to Choi (2004, p. 1214), two thirds of the respondents in his analysis agree that there is more mutual cooperation in housing communities than in conventional neighborhoods.

Although not directly comparable, evidence from "Aging in Place"-projects and "Continuing Care Retirement Communities" also provides some insight into the appropriate design of housing projects for seniors: Shippee (2009) points to the high importance of privacy and autonomy on the one hand and social integration on the other hand. Even in "Continuing Care Retirement Communities", transitions between the stages of independent living, assisted living and nursing living are experienced as stressful due to the loss of personal autonomy, privacy and social integration. This calls for both: facilitating communication and improving conditions for privacy by creating more personal space. The crucial role of organizational policies for the perception of residents' autonomy is highlighted by Sikorska-Simmons (2006): more opportunities for personal choice on a level that corresponds to the residents' level of physical and mental abilities are conducive to higher perception of autonomy and living satisfaction. Similarly, Burge and 
Street (2009) reveal that - after controlling for different resident and facility characteristics - the quality of co-resident relationships in assisted living facilities is positively correlated with maintaining contacts with pre-AL friends and family members outside the facility.

Evidence on the cost effectiveness of mutual support based housing projects is very limited to our knowledge: Jenkins et al. (2002) state that the level of discretionary activities among residents of Continuing Care Retirement Communities is positively correlated with indicators for health related quality of life - which should implicitly be negatively related to health costs, although this is not explicitly discussed by the authors. An analysis of the TigerPlace Aging in Place project at the University of Missouri assumes some cost savings in the assistance of frail elderly in a new model of long term care. The project allows for independent living of residents in adequately constructed, private apartments, supported by coordinated nursing care on a case by case basis and continuous monitoring of health (Rantz et al., 2008).

Summarizing prior evidence, there is some reason to suppose that new housing projects aiming at mutual support of residents are often quite successful in improving living quality of residents. But to our knowledge there exists no analysis of the relative costs of mutual support based housing projects in comparison to conventional living arrangements - which is the actual motivation for our study.

\section{Description of the SONG housing projects}

The four housing projects which we analyze in this study are all part of the $\mathrm{SONG}^{2}$ network, run by four major German non-profit-organizations. Even if these projects differ widely with regard to the sociodemographic structure of the residents, they have a common focus on mutual neighborly support and on its encouragement and moderation by a social worker. In the following, we briefly describe the projects in the alphabetical order of their geographic location.

2 SONG stands for Soziales Neu Gestalten which may be translated as Designing Social Action Alternatively. 


\section{Bielefeld}

The housing estate "Heinrichstrasse" in the city of Bielefeld is run by the Protestant Johanneswerk organization. Elderly as well as physically disabled people of all age groups live in 42 apartments, where two apartments are intended for wheelchair users. Aid and care is provided 24 hours each day by the Johanneswerk, but to be able to work profitably, six apartments are intended for persons with high care requirements who need assistance all day. Furthermore, caregivers help residents with housekeeping or give other support. Those caregivers, a social worker responsible for coordination, a volunteer responsible for providing lunches, and six further volunteers promote the residents' community life. They encourage residents to organize activities themselves, accompany them to cultural events or to the city centre, and offer leisure-time activities in cooperation with the church and other associations.

\section{Bremen}

The residents of the project "Haus im Viertel" in the city of Bremen, which is run by the foundation Bremer Heimstiftung, are rather homogenous with regard to their age. The intention of the project is to enable the elderly as well as disabled residents who live in one of the 92 apartments to remain in their familiar district and thus to keep their social life, even in case of increasing need for aid and care. The promotion of neighborly assistance within and outside the residence is the essential idea behind the project, rather than the provision of services. To this end, the manager of the residence encourages people to design the building, the gardens, and the recreation room jointly and to help each other in case of need. Her function is to give impulses, to facilitate, and to arrange professional support if needed. Care arrangements may be made with a provider which is closely located to the residence.

\section{Liebenau}

The Liebenau foundation owns several housing projects of varying size in the rural area of Liebenau in southern Germany. In our study, we included five different locations labeled "Lebensräume für Jung und Alt" (Living Spaces for Young and Old), comprising 39 to 84 
apartments each. In contrast to conventional old peoples' homes, these projects are intentionally designed to be generation-spanning. The project aims at avoiding the need for professional care services and replacing them by self-help or assistance provided by neighbors. Firstly, these concerns are met by architectural features (accessibility, common rooms), and secondly, a social worker advises residents, encourages joint activities, and moderates conflicts. In case professional care is needed, this is provided by the services of the Liebenau foundation or external providers.

\section{Wipperfuerth}

The multigenerational house in the rural area of Wipperfuerth, near Cologne, is run by the Catholic Caritas holding company (CBT). Here, individuals of different age and marital status and in various living circumstances live together. The housing estate comprises two buildings, summing up to 35 accessible apartments and a community room which is available to the residents. The residents themselves are responsible for the move-in of new tenants, the design of the garden, and the community room. A social pedagogue supports them and moderates the residents' meeting which is held every two months. The provision of professional care or other professional services is not part of this concept.

\section{Methodological approach}

\subsection{Social return on investment as a heuristic guideline}

The social return on investment (SROI) approach provides a methodological guideline for our analysis. ${ }^{3}$ The SROI concept intends to measure the economic outcome on the private household, project or company level as well as the social value added of social projects. Therefore, the SROI model basically distinguishes between three different categories of value: the economic value and socioeconomic value, both measurable in monetary terms, and the social value added, which cannot be assessed in monetary terms but described only qualitatively (see fig. 1). Examples for socio-economic value are net monetary returns of

3 For an introduction in the SROI methodology, see Roberts Enterprise Development Fund (2000). 
social projects on the societal level, i.e. the difference between additional yield (i.e. generated additional tax payments, additional sales returns, lower costs for support) and additional costs of a social project (e.g. additional personnel costs for social workers to encourage mutual support and joint activities). Social value added refers to qualitative aspects, i.e. to increased work satisfaction, housing satisfaction or general life satisfaction.

Figure 1: Categories of value in the SROI concept

\section{- Economic Value:}

economic yield, conventionally defined and quantified in monetary terms, on individual and project level

\section{- Socio-Economic Value:}

value added on societal level, quantified in monetary terms

\section{- Social Value:}

value added, not quantifiable in monetary terms

SROI analyses therefore systematically take external effects into account which are neglected in conventional economic valuation. In contrast to the approach pursued by most SROI studies, however, we have not calculated net present values of the projects. As an alternative, we compared costs in the SONG housing projects with costs in conventional housing for a representative period. The central indicator in the framework of our SROI analysis therefore is the cost of support for older residents with identical need for assistance. Lower average costs of support in the new housing projects can in this concept be interpreted as additional (socio-) economic value in SROI categories. In practice, however, it is not always possible to draw a clear distinction line between effects on the individual level, on the project level and on the overall societal level. The financing structures for support and care of frail elderly are usually complex and involve own payments by private households, contributions by relatives and friends, contributions covered by social insurance and municipalities as well as subsidies by the non-profit organizations which run the housing projects. Due to this complexity of the financing structures it seems preferable to use an aggregate cost measure. Cost advantages measured 
by this indicator can be interpreted as a potential for cost savings manifesting themselves depending on their allocation - on different levels.

\subsection{Survey design and data sources}

Our SROI analysis is based on an extensive survey among the residents of the four housing projects which we described above and is complemented by a business-level analysis of the projects. The survey among the residents was designed to collect data on the extent to which assistance is needed - especially by the elderly - and on how this assistance is provided. Furthermore, we collected information on community life in the projects and the integration of the residents in the respective geographical district. Chapter 5.1 gives information on the survey sample and delivers some descriptive statistics.

By means of the business-level analysis, we collected data from the managing non-profit organizations on costs and yields resulting from the projects. These data reflect an average business period and thus exclude extraordinary events. To make the capital flows comparable between the various housing projects we converted the data: all costs, in particular financing costs, were valued on the basis of opportunity costs to preclude distortions through public subsidies or cross-subsidies of the managing organizations. This method produced a yearly surplus or deficit for each of the housing projects, which is corrected for the number of residents and the living space, respectively.

To isolate the effects of living in one of the four housing projects on the need for care and assistance, we compare the residents of those projects, i.e. the treatment group with a control group which we recruited for that purpose. The main criteria for the composition of the control group were provided by the survey results of the treatment group: One important criterion were the answers to the question: what would be the most likely alternative living situation in case that individuals would not be able to live in one of the housing projects. Members of the control group were asked to answer the same questionnaire as members of the treatment group did. If control group individuals lived in old-age homes, we conducted another business-level analysis to gather data on the costs of 
these homes. The composition of the control group and further descriptive statistics may be found in chapter 5.1 .

The comparison of the treatment and the control groups is done by applying the method of propensity score-matching. This method is often used for microeconometric policy evaluation and is based on a comparison of individuals whose propensity to receive a certain treatment is as close as possible. In our context, this means that we compare individuals whose propensity to live in one of the four housing projects is as similar as possible.

The cost differential between the treatment group and the control group may be interpreted as additional gain or cost resulting from individuals living in one of the housing projects in a strict monetary meaning. Furthermore, additional social gains or costs which are of a rather qualitative nature may occur. These are determined by comparing indicators for social cohesion and mutual support among neighbors in the treatment and control groups.

\subsection{Econometric Approach: Propensity Score Matching}

Our study systematically analyses whether living in the SONG housing projects has a measurable impact on the need for assistance of their residents, on the pattern of support provision and on the costs associated with it. Methodologically, this approach encounters the difficulty that we can survey the residents of the new housing projects only in their current living situation. We cannot obtain any comparable observation for the same individuals in other housing arrangements to measure the "treatment effect" of the new housing concepts. The „Average Treatment Effect on the Treated“(ATT) is the difference between the outcome $\mathrm{Y}(1)$, observed for individual $\mathrm{i}$ as resident of one of the new housing projects $\left(D_{i}=1\right.$ for residents of new housing projects, $D_{i}=0$ for non-residents), minus the result $\mathrm{Y}(0)$ which would be observed if individual i would not live in this housing project.

$$
A T T=E\left(T_{i} \mid D_{i}=1\right)=E\left[Y_{i}(1) \mid D_{i}=1\right]-E\left[Y_{i}(0) \mid D_{i}=1\right]
$$


To derive statistically valid treatment effects, evaluation studies frequently use matching approaches $^{4}$ to compare individuals with similar characteristics living in different situations (in our case: in one of the new housing projects or in the control group). To obtain reliable statistical results, the Conditional Independence Assumption (CIA) must be fulfilled. This means that the results must not be determined only by membership in one of both groups. It has to be assumed that the distribution of individuals between treatment group and control group is completely random and depends only on characteristics which are controlled for in the econometric matching model (in the vector of exogenous variables $\mathrm{X})$. Formally, the CIA states that

$$
Y_{i}(1), Y_{i}(0) \coprod D_{i} \mid X_{i}, \forall X
$$

Whether the CIA holds cannot be proved in general but can be tested for the variables in X. In particular, we can check whether average values for $\mathrm{X}$ variables differ between residents and non-residents. Equally important is the assumption of common support, meaning that for all individuals with same $\mathrm{X}$ values, the probability of being either a member of the treatment group or not is positive. Formally:

$$
0<P(D=1 \mid X)<1
$$

The higher the number of exogenous variables in $\mathrm{X}$, the lower is the number of individuals with exactly identical $\mathrm{X}$ values. To reduce this problem of dimensionality, a propensity score is usually calculated. This propensity score is the estimated probability that an individual belongs to the group of the treated (the SONG residents in our case), given the values in X. According to Rosenbaum and Rubin (1983), we can use these propensity scores to compare observations among members of the treatment group and the control group. Ideally, only individuals with identical propensity scores should be compared. However, this is still a strong assumption, usually leading to a loss of too many observations. In practice, therefore, similar propensity scores are included in the matching process as well.

4 Cf. the seminal work by Rosenbaum and Rubin (1983), for application-oriented discussion 
In our analysis, we apply a radius matching: this technique compares all observations in the treatment group with those observations in the control group which have propensity scores within a certain radius. This approach is advantageous because it excludes bad matches outside the radius, but includes as many observations as possible within the radius and therefore mitigates individual outliers.

We calculated four different alternatives for the matching of treatment and control group. These models differ with respect to the age structure of the samples and use different $\mathrm{X}$ variables to calculate the propensity scores. Basically, we distinguished between the whole sample and a subsample, comprising only individuals aged 50 or older (in the following: the sample 50+). We selected this age limit for statistical as well as for material reasons. On the one hand, in the 50+ group the need for support is substantially increasing compared to average values for the total sample. On the other hand, particularly the younger people in the sample $50+$ are still able to provide substantial support to others in the neighborhood.

Additionally, we calculated the propensity scores in two versions based on different assumptions:

- Version 1 includes, as the exogenous variable for the calculation of propensity scores, data on the health status and the need of care that refer to the point of time when people were moving to the new housing projects.

- Version 2 refers to the date of the survey and includes current health status and need of care information as exogenous variables.

Version 1 assumes that observable differences between treatment group and control group in health status and need for care at the time of the survey do not distort the results because there were no significant differences before moving in. In other words: it is assumed that observable differences can be attributed to the different housing and living conditions in

Caliendo and Kopeinig (2005), Dehejia and Waba (2002). 
treatment and control group. If we observe that residents in the treatment group are healthier and need less professional care than in the control group, version 1 attributes this positive effect to the influence of the housing and living environment in the SONG projects.

Version 2 implies on the contrary that health and need-for-care development are rather independent from the environment. If we can observe differences at the time of the survey, they are rooted in unobservable differences already existing before residents moved in. One might assume for example, that individuals facing the threat of deteriorating health status have decided for living in a conventional nursing home or in assisted housing, while those with better expectations have chosen one of the SONG projects. Version 2 therefore is based on more conservative assumptions, and provides a robustness check for results that can be obtained in version 1 .

As a further difficulty, the length of stay in the current housing situation differs to some extent systematically between treatment group and control group. Particularly the members of the control group who live independently in their own apartments or houses have sometimes stayed much longer in their current housing situation than the residents of the SONG projects or residents of conventional old peoples' homes. These are typically individuals with a good health status, which allows them to live rather independently on their own. To control for this possible distortion of our results, we did several sensitivity checks by excluding older cohorts of movers (moving in before 1995 or 2000, alternatively) and by using current health and care status of this subgroup instead of the status before moving in. However, this changes our results only to a minor extent.

To briefly summarize: if the development of the health conditions in the treatment group is better than in the control group, this would be treated as exogenous in version 2. Resulting cost advantages (lower costs for support and care) would not be attributed to the new housing projects. Version 2 can therefore be interpreted as a kind of robustness check for version 1, assuming that we are not able to reveal all differences in health status before moving in, that results might be distorted by different durations in the respective housing 
situations and/or that observable differences in health conditions are exogenously determined.

\subsection{Estimation of propensity scores}

The propensity score was estimated in a probit model, including the following variables

- age (in years)

- $\quad \operatorname{sex}($ dummy variable $=1$ if male $)$

- number of children under age ten in household

- household size (number of persons)

- education (dummy variable $=1$, if head of household is highly qualified, else 0$)^{5}$

- income (in five intervals)

- number of physical diseases (alternatively: before moving in or at the time of the survey, number of items)

- care level (alternatively: before moving in or at the time of the survey, dummy variable $=1$ if care level $>0$ )

- handicapped (degree)

- voluntary engagement before moving in ${ }^{6}$ (dummy variable $=1$, if head of household has engaged herself, else 0)

- information on current living situation (control group) or preferred alternative housing situation if not living in the SONG projects (treatment group) (dummy variable $=1$ if current/preferred living situation is assisted housing or care/nursing home, else 0$){ }^{7}$

5 High qualification was defined as „Meister/Techniker“ (foreman/technician) and comparable qualifications, and university degrees

6 As far as members of the control group, living solitary in their own household, are concerned: if their last move was not earlier than 5 years ago. For all other cases the answers for the current activity at the time of the survey were inserted. 
This vector includes a number of exogenous socio-demographic variables that might theoretically influence the probability to move into one of the SONG projects. Besides age, sex, size of household and number of (small) children, especially the variables on the health status are important, because in particular a certain health condition could have motivated elder people to move into one of the new housing projects. The information on the current (control group) or alternatively preferred (treatment group) housing situation contains some hidden information on the health condition, but reflects also individual housing preferences and viability of alternatives. The dummy variable indicating the prevalence of voluntary engagement in prior life takes into consideration that individuals with a high propensity to voluntary engagement might decide to move into one of the SONG housing projects with higher probability.

The estimates for calculation of the propensity scores yields a McFadden Pseudo $\mathrm{R}^{2}$ of 20\% (see Tab. 10 to Tab. 13 in the appendix). This proves that our model has reasonable explanatory power with regard to the assignment of individuals to the treatment group or the control group. The lack of an even higher power of the estimates should not be regarded as a weakness in our context. It proves on the one hand that the sample of residents in our survey is rather heterogeneous and that it is hard to determine the probability of participation in the treatment group simply based on socio-demographic and individual characteristics. On the other hand, this $\mathrm{R}^{2}$ demonstrates that treatment group and control group are already rather similarly structured. The variance of the propensity scores is therefore lower than it would be with strongly diverging group compositions. In other words: a lower $\mathrm{R}^{2}$ indicates a lower need for structural adjustment of the samples in the matching procedure. ${ }^{8}$

Our analysis is based on a radius matching with a narrow radius of 0.05 , meaning that the estimated probability for being a member of the treatment group should not differ by more

7 The corresponding question was: Where would you live if you would not be able to live in this housing project: in an old peoples' home/a nursing home, in assisted housing, solitary in your own household/in one household with relatives or friends? 
than five percentage points. We chose this procedure, because we regard it as a good compromise between a Nearest-Neighbor-Matching with potentially weak matches and the strong restrictions of a Caliper-Matching. ${ }^{9}$ For the impact of the matching on average values of the variables in the $\mathrm{X}$ vector, see Tab. 14 to Tab. 17 in the appendix.

\subsection{Descriptives}

Altogether, we conducted interviews with 490 households, 222 of which in the treatment group and 268 in the control group, covering a total of 740 individuals, 312 of which in the treatment group and 428 in the control group. Tab. 1 displays descriptive statistics of a subset of variables both for the treatment and the control group.

\section{Tab. 1: Descriptive Statistics}

\begin{tabular}{|l|c|c|}
\hline Variable & Treatment Group & Control Group \\
\hline Age & 57.78 & 56.64 \\
\hline Female & 0.69 & 0.61 \\
\hline Living in Single Household & 0.52 & 0.40 \\
\hline Living in High Income Household & 0.04 & 0.42 \\
\hline (Very) Good Health & 0.51 & 0.60 \\
\hline Care Level (Yes) & 0.11 & 0.17 \\
\hline Disabled & 0.22 & 0.22 \\
\hline Life Satisfaction & 8.30 & 8.75 \\
\hline
\end{tabular}

Table displays variable means. Standard deviation in parentheses.

8 In accordance with this argument, Sianesi (2004) recommends an analysis of the pseudo- $\mathrm{R}^{2}$ to check the validity of the matching. A low $\mathrm{R}^{2}$ points to a small distortion through remaining differences in the samples. See also Caliendo/Kopeinig 2007: 16.

9 Only in version 2 for the group $50+$ we had to enlarge the radius to .2 to further reduce structural differences between the samples. 
With regard to individuals' age both groups are very similar: Members of the treatment group are on average 57.78 years old, whereas members of the control group are on average only slightly younger (56.64 years). The share of females is higher in the treatment group $(69 \%)$ than in the control group $(61 \%)$, the same is true for the share of individuals living in single households (52\% versus $40 \%)$. The difference is very pronounced, however, for the percentage of individuals living in high income households, i.e. households which have more than $2,500 €$ per month available, only $4 \%$ of treatment group members and even $42 \%$ of control group members answered accordingly. Looking at some health variables, both groups are quite similar to each other: $51 \%$ of the individuals living in one of the four housing projects claim to be of (very) good health, compared to $60 \%$ in the control group. The percentage of disabled individuals is $22 \%$ for both subsets, but while $11 \%$ of treatment group members are officially acknowledged as being in need of care, the share is $17 \%$ in the control group. Nevertheless, members of the control group on average seem to be slightly more satisfied with their current life situation than members of the treatment group on a scale ranging from 0 (completely unsatisfied) to 10 (completely satisfied).

\subsection{Comparison of residents' need for care and support}

Core of our economic analysis is the comparison of costs for the assistance of needy residents in the treatment group and the control group. As already said, our analysis comprises different versions: In a first version, we use the health conditions before moving into the SONG projects as a matching criterion; in the second version, the health status at the time the survey was conducted is used.

If we first look at the demand for help, we observe in the first version that health conditions and need for care are significantly different between treatment and control group at the time the survey was conducted, although no significant difference was observable before residents moved in (see Tab. 2). In the total sample of SONG residents, $13 \%$ of all residents are officially acknowledged as being in need of care, the 
corresponding share in the control group is $22 \% .{ }^{10}$ If this is weighed by officially classified degrees of need for care (until 2008 the German system distinguished 3 different levels from level 1 (some need of daily assistance) to level 3 (continuous need of intense care)), the respective values are 0.19 for the treatment group and 0.28 in the control group. Accordingly, at the time of the survey we count a significantly higher number of reported items for the number of serious physical handicaps and diseases in the control group: the difference to the treatment group amounts to around 0.4 reportings. ${ }^{11}$ Before moving in, there was no significant difference between treatment and control group in version 1. Expectedly, the differences are even more pronounced if we constrain our analysis to the sample $50+$ (see Tab. 3). The share of residents in need of care is $16 \%$ in the SONG housing projects, while we observe $33 \%$ in the control group. Weighed with levels for need of care, the index is 0.23 for the treatment group vs. 0.41 for the control group. The difference in the prevalence of serious handicaps and diseases is 0.77 , which is markedly higher than in the total sample.

The differences in the health conditions at the time of the survey result in different needs for assistance. Some need for assistance in daily life is reported by $39 \%$ of respondents in the treatment group and $46 \%$ in the control group. This difference is not significant on usually applied significance levels. If we distinguish between categories of help providers, we observe negatively signed differences - corresponding to lower need for help in treatment than in control group - in almost all categories. Particularly impressive is the difference in institutional support (assistance provided by institutions which run the housing projects). This effect can be explained by the residents in the control group living in assisted housing and old peoples' homes/nursing homes.

Remarkable, on the other hand, is that in spite of the (insignificantly) lower need for assistance between the groups, a positive difference is observable for mutual support by

10 The shares mentioned here and in the following refer - differing from the descriptive analysis to the sample used in the matching. Therefore the shares reported deviate from the shares of the descriptive analysis.

11 Calculated as number of reported serious physical handicaps and chronic diseases, divided by the number of persons. 
other residents. Although the absolute numbers are not very high, this can be interpreted as a first hint that the neighbors indeed provide subsidiary support to a higher extent in these new housing projects than in conventional living situations. If we limit our observations to the sample 50+, we detect in general even stronger effects. In particular, the need for daily support is significantly higher in this group, and it is significantly different between treatment and control group. The support patterns resemble those in the total sample. We can observe a significant positive difference for the item "support by other residents" as well.

With regard to version 2 - based on matched individuals with identical health conditions and need for care -, we can still observe some weakly significant differences between the group of SONG residents and the control group (see Tab. 4 and Tab. 5). This might be explained by the fact that our (subjective) indicators for health condition are too rough to catch all differences in detail. But it is also not unlikely that positive effects of the housing environment and neighborhood effects play some role here. In particular, one can imagine that residents of SONG projects do not resort to professional daily support to some extent because social contact can easily be established within the neighborhood. Furthermore, it is possible that - in particular in comparison to the residents in the control group not living in assisted housing or old peoples' homes - the infrastructure in the dwellings of the SONG projects (accessibility for handicapped) renders some support obsolete. 
Tab. 2: ATT Health conditions and need for assistance (total sample, version 1)

\begin{tabular}{|l|l|r|r|r|r|}
\hline Variable & Dimension & Treatm. & Control. & Diff. & Significance \\
\hline Health status (subjective) & Scale 1-10 & 2.59 & 2.53 & 0.06 & \\
\hline Diseases & Number & 1.03 & 1.40 & -0.37 & $* *$ \\
\hline Need of Care & Dummy & 0.13 & 0.22 & -0.08 & $(*)$ \\
\hline Care Level & Scale 0-3 & 0.19 & 0.28 & -0.09 & $(*)$ \\
\hline & & & & & $(*)$ \\
\hline Assistance in daily living & Dummy & 0.39 & 0.46 & -0.08 & \\
\hline Assistance in daily living & Number & 0.71 & 0.87 & -0.16 & \\
\hline Assistance in daily living & Time & 2.93 & 3.11 & -0.17 & $* * *$ \\
\hline Assistance: external care provider & Dummy & 0.07 & 0.07 & 0.00 & \\
\hline Assistance: non-profit organization & Dummy & 0.06 & 0.20 & -0.14 & \\
\hline Assistance: spouse & Dummy & 0.02 & 0.04 & -0.02 & \\
\hline Assistance: family & Dummy & 0.19 & 0.24 & -0.05 & \\
\hline $\begin{array}{l}\text { Assistance: neighbors/friends } \\
\text { outside }\end{array}$ & Dummy & 0.04 & 0.07 & -0.02 & \\
\hline Assistance: other residents & Dummy & 0.06 & 0.02 & 0.05 & \\
\hline Assistance: therapists & Dummy & 0.09 & 0.10 & -0.01 & \\
\hline Assistance: other service providers & Dummy & 0.16 & 0.13 & 0.03 & \\
\hline Source: Authors calculyon & & & & & \\
\hline
\end{tabular}

Source: Authors' calculations, radius $0.05 . * * * * * / * /(*)=$ Level of significance $>99 / 95 / 90 / 80 \%$. 
Tab. 3: ATT Health conditions and need for assistance (sample 50+, version 1)

\begin{tabular}{|l|l|r|r|r|r|}
\hline Variable & Dimension & Treatm. & Control. & Diff. & Significance \\
\hline Health status (subjective) & Scale 1-10 & 2.98 & 3.07 & -0.09 & \\
\hline Diseases & Number & 1.36 & 2.13 & -0.77 & $* * *$ \\
\hline Need of Care & Dummy & 0.16 & 0.33 & -0.17 & $* * *$ \\
\hline Care Level & Scale 0-3 & 0.23 & 0.41 & -0.18 & $* *$ \\
\hline & & & & & $* * *$ \\
\hline Assistance in daily living & Dummy & 0.50 & 0.71 & -0.21 & $* * *$ \\
\hline Assistance in daily living & Number & 0.90 & 1.40 & -0.50 & \\
\hline Assistance in daily living & Time & 3.79 & 3.97 & -0.18 & $* * *$ \\
\hline Assistance: external care provider & Dummy & 0.09 & 0.12 & -0.02 & \\
\hline Assistance: non-profit organization & Dummy & 0.06 & 0.35 & -0.28 & \\
\hline Assistance: spouse & Dummy & 0.02 & 0.05 & -0.03 & \\
\hline Assistance: family & Dummy & 0.26 & 0.43 & -0.17 & \\
\hline $\begin{array}{l}\text { Assistance: neighbors/friends } \\
\text { outside }\end{array}$ & Dummy & 0.06 & 0.10 & -0.04 & \\
\hline Assistance: other residents & Dummy & 0.07 & 0.03 & 0.04 & \\
\hline Assistance: therapists & Dummy & 0.09 & 0.14 & -0.05 & \\
\hline Assistance: other service providers & Dummy & 0.24 & 0.19 & 0.06 & \\
\hline Sourc: Authos calculations & Dump & & & & \\
\hline
\end{tabular}

Source: Authors' calculations, radius $0.05 . * * * * * / * /(*)=$ Level of significance $>99 / 95 / 90 / 80 \%$. 
Tab. 4: ATT Health conditions and need for assistance (total sample, version 2)

\begin{tabular}{|l|l|r|r|r|r|}
\hline Variable & Dimension & Treatm. & Control. & Diff. & Significance \\
\hline Health status (subjective) & Scale 1-10 & 2.59 & 2.48 & 0.11 & \\
\hline Diseases & Number & 1.03 & 1.20 & -0.16 & \\
\hline Need of Care & Dummy & 0.13 & 0.18 & -0.04 & \\
\hline Care Level & Scale 0-3 & 0.19 & 0.22 & -0.03 & \\
\hline & & & & & \\
\hline Assistance in daily living & Dummy & 0.39 & 0.44 & -0.05 & \\
\hline Assistance in daily living & Number & 0.71 & 0.79 & -0.08 & \\
\hline Assistance in daily living & Time & 2.93 & 2.63 & 0.31 & \\
\hline Assistance: external care provider & Dummy & 0.07 & 0.07 & 0.00 & \\
\hline Assistance: non-profit organization & Dummy & 0.06 & 0.17 & -0.12 & \\
\hline Assistance: spouse & Dummy & 0.02 & 0.04 & -0.01 & \\
\hline Assistance: family & Dummy & 0.19 & 0.22 & -0.03 & \\
\hline $\begin{array}{l}\text { Assistance: neighbors/friends } \\
\text { outside }\end{array}$ & Dummy & 0.04 & 0.07 & -0.02 & \\
\hline Assistance: other residents & Dummy & 0.06 & 0.02 & 0.05 & \\
\hline Assistance: therapists & Dummy & 0.09 & 0.07 & 0.02 & \\
\hline Assistance: other service providers & Dummy & 0.16 & 0.14 & 0.03 & \\
\hline Source: Au* & & & & & \\
\hline
\end{tabular}

Source: Authors' calculations, radius $0.05 . * * * * * / * /(*)=$ Level of significance $>99 / 95 / 90 / 80 \%$. 
Tab. 5: ATT Health conditions and need for assistance (sample 50+, version 2)

\begin{tabular}{|c|c|c|c|c|c|}
\hline Variable & Dimension & Treatm. & Control. & Diff. & Significance \\
\hline Health status (subjective) & Scale 1-10 & 3.00 & 2.94 & 0.06 & \\
\hline Diseases & Number & 1.38 & 1.55 & -0.17 & \\
\hline Need of Care & Dummy & 0.17 & 0.24 & -0.07 & \\
\hline Care Level & Scale 0-3 & 0.23 & 0.29 & -0.06 & \\
\hline Assistance in daily living & Dummy & 0.51 & 0.62 & -0.11 & * \\
\hline Assistance in daily living & Number & 0.91 & 1.15 & -0.24 & $(*)$ \\
\hline Assistance in daily living & $\begin{array}{l}\text { Time } \\
\text { (hours/week) }\end{array}$ & 3.71 & 3.08 & 0.63 & \\
\hline Assistance: external care provider & Dummy & 0.10 & 0.09 & 0.01 & \\
\hline Assistance: non-profit organization & Dummy & 0.07 & 0.28 & -0.22 & $* * *$ \\
\hline Assistance: spouse & Dummy & 0.02 & 0.04 & -0.02 & \\
\hline Assistance: family & Dummy & 0.25 & 0.32 & -0.07 & \\
\hline $\begin{array}{l}\text { Assistance: neighbors/friends } \\
\text { outside }\end{array}$ & Dummy & 0.06 & 0.10 & -0.04 & \\
\hline Assistance: other residents & Dummy & 0.08 & 0.03 & 0.05 & * \\
\hline Assistance: therapists & Dummy & 0.10 & 0.10 & 0.00 & \\
\hline Assistance: other service providers & Dummy & 0.23 & 0.18 & 0.05 & \\
\hline
\end{tabular}

Source: Authors' calculations, radius $0.2 . * * * / * * / * /(*)=$ Level of significance $>99 / 95 / 90 / 80 \%$.

\subsection{Comparison of costs for the provision of support and care}

\subsubsection{Imputation of cost variables}

The survey responses regarding costs for daily assistance and care do not seem very reliable for a substantial part of surveyed individuals. In many cases, information on costs which are covered by residents themselves is missing. When costs are covered by social insurance (care insurance, health insurance), respondents frequently merely reported the source of finance but not the amount that is actually paid. For these reasons, missing and not plausible data (if provision of professional assistance but no cost was reported) had to 
be imputed. If costs were covered by care insurance, it was assumed that the maximum amount directly paid to care providers at the respective level was regularly demanded by these providers. ${ }^{12}$ All remaining costs for services covered directly by residents would then have to be paid totally by themselves without any further reimbursement by social insurance. For residents of nursing homes in the control group we imputed the payments for care included in total monthly costs per resident. We calculated this amount by subtracting costs for housing and nutrition from total costs (information was provided by the organization managing the nursing homes). ${ }^{13}$ In all cases in which costs were not reported to be covered by social insurance, information for missings was imputed based on information of reported cases. We imputed average time weighted values, separately calculated for expenses covered by residents themselves, by their relatives or by the health insurances.

All imputations were calculated for all individuals. This approach certainly bears some risk of leveling out cost differences between treatment group and control group and between different institutions within each group to some extent. However, it was not possible to impute values based on the sometimes very small number of cases in every project and location. Therefore: if we are able to find cost differences at all, our results would have to be interpreted as minimum values that are mitigated to some extent by variance reducing imputation.

\subsubsection{Results of cost comparisons}

The cost differences are rather heterogeneous, based on the different assumptions underlying version 1 and 2. Version 1, based on similar health conditions and need of care before moving in, shows significant cost advantages for the treatment group compared to the control group (see Tab. 6 for an overview, for details refer to Tab. 18 to Tab. 21 in the

12 At the time of the survey, the amount for care level 1 was 384 Euro, for level 2,921 Euro and for level 3 1,432 Euro per month.

13 Haus Huchting: care level 1 1,096.16 Euro, level 2 1,753.98 Euro, level 3 2,192.32 Euro; Stiftungsdorf Hollergrund: level 1 1,098.64 Euro, level 2 1,757.70 Euro, level 3 2,197.28 Euro, 
appendix). The cost advantages are substantial: If we account only for the costs covered by the residents or their social insurance, costs are around 50\% lower in the new housing projects than in the control group. Including additional costs for the organizations running the projects, cost advantages decrease to around 30\%; this lower difference in total costs clearly implies, that lower individual costs come not for free but only at the cost of additional expenses from the managing organizations.

If we assess only the group 50+, cost advantages are even larger (self-covered and insurance covered costs differ by more than $65 \%$, total costs by around $50 \%$ ). Even if we treat the development of health conditions and need for care as exogenous, cost differences still exist. For the total sample, cost advantages in the treatment group are still around $20 \%$, but are not statistically significant any more. If we limit our focus to the 50+ sample, we can still observe significant differences of more than $36 \%$ of total costs.

How can these enormous cost differences be explained? This question arises particularly with respect to version 2 , based on similar average health conditions in the subsamples. A good part of the cost differences can be explained by the higher costs for residents, living in nursing homes. A sensitivity analysis, excluding residents of nursing homes and their equivalents in the treatment group (all residents reporting an old peoples' home/nursing home as their preferred housing alternative), yields very different results. In this analysis, we cannot observe significant differences between both groups any more (see Tab. 22 to Tab. 25 in the appendix).

Summarizing our findings on the cost situation, we can therefore draw a positive conclusion for the treatment group, even aware of the small sample size, missing survey data and the variance-reducing data imputations:

- In the treatment group we can observe - based on admittedly rough indicators of the subjectively assessed health condition - a better development of the health condition than in the control group.

Haus Fichtenhof: level 1 1,107.32 Euro, level 2 1,771.65 Euro, level 3 2,214.64 Euro per month. 
- Even if we assume that the development of health conditions is exogenously determined, we find - at least for the group 50+ - significant cost advantages of the new housing projects.

- The prevalence of residents with a high need of care, who would have to live in nursing homes if not living in the SONG projects, has a decisive impact on the level of cost differences. On the other hand, we have to take into consideration that cost differences are mitigated by our imputations which contributes to the low level and insignificance of the differences in the sensitivity analysis without nursing home residents.

- A part of the cost differences may be explained by differences in mutual support of residents. We can observe that mutual support is more frequently reported in the new housing projects than in the control group, although the need for assistance in general is lower. Answers on a more detailed question on the pattern of mutual support by neighbors reveal that this kind of support refers to practical assistance, e.g. in housekeeping, crafting, shopping, showing up at local authorities etc.). ${ }^{14}$ In contrast to this, actual provision of care services in a medical sense does not play a major role.

- We should also point out, that differences even if they prove to be statistically significant, have a considerable variance. This is shown in Tab. 7 reporting the confidence intervals for total cost differences. Here, we see that for the group 50+, the difference in version 1 varies between 144 Euros and 394 Euros in the $90 \%$ confidence interval. In version 2, the limits of the $90 \%$ interval are 45 Euros and 259 Euros. This proves that our results are rather tentative and should be interpreted as an empirical regularity, but should not be taken as literal regarding the exact level of cost differences.

14 This additional question referred not only to daily assistance but to mutual support by neighbors also on an irregular, occasional basis (for results, see Tab. 27 and Tab. 28) 
Tab. 6: Overview of total cost differences between treatment and control group

\begin{tabular}{|l|r|r|r|r|}
\hline & \multicolumn{2}{|c|}{ Version 1 } & \multicolumn{2}{c|}{ Version 2 } \\
\hline & total sample & $50+$ & total sample & $50+$ \\
\hline all residents & $\mathbf{- 3 0 . 9 \%}$ & $\mathbf{- 5 0 . 1 \%}$ & $-20.6 \%$ & $\mathbf{- 3 6 . 0 \%}$ \\
\hline w/o nursing home residents & $-4.7 \%$ & $-25.7 \%$ & $9.8 \%$ & $-12.3 \%$ \\
\hline
\end{tabular}

Source: Authors calculations, bold values significant. Total costs, partly imputed.

Tab. 7: 90\%-confidence intervals for difference between treatment and control group (total costs/all residents), in Euro per month

\begin{tabular}{|l|r|r|r|r|}
\hline & \multicolumn{2}{|c|}{ Version 1 } & \multicolumn{2}{c|}{ Version 2 } \\
\hline & total sample & $50+$ & total sample & $50+$ \\
\hline Lower bound & $\mathbf{- 2 0 5 . 4 9}$ & $\mathbf{- 3 9 4 . 4 8}$ & -160.74 & $\mathbf{- 2 5 9 . 0 6}$ \\
\hline Upper bound & $\mathbf{- 1 3 . 4 3}$ & $\mathbf{- 1 4 4 . 2 1}$ & 33.56 & $\mathbf{- 4 4 . 7 5}$ \\
\hline
\end{tabular}

Source: Authors' calculations, bold values significant. Total costs, partly imputed.

Tab. 8: ATT Mutual support among neighbors (total sample)

\begin{tabular}{|l|l|r|r|r|r|}
\hline & Dimension & Treatm. & Cont. & Diff. & Significance \\
\hline $\begin{array}{l}\text { Support received from } \\
\text { neighbors }\end{array}$ & Dummy & 0.37 & 0.32 & 0.05 & \\
\hline Support given to neighbors & Dummy & 0.51 & 0.34 & 0.17 & $* * *$ \\
\hline $\begin{array}{l}\text { Support received from } \\
\text { neighbors }\end{array}$ & Number & 0.76 & 0.55 & 0.21 & $*$ \\
\hline Support given to neighbors & Number & 1.37 & 0.67 & 0.69 & $* * *$ \\
\hline
\end{tabular}

Source: Authors' calculations, radius 0.05, version 1. $* * * * * / * /(*)=$ Level of significance $>99 / 95 / 90 / 80 \%$. 
Tab. 9: ATT Mutual support among neighbors ( 50+)

\begin{tabular}{|l|l|r|r|r|r|}
\hline & Dimension & Treatm. & Cont. & Diff. & Significance \\
\hline $\begin{array}{l}\text { Support received from } \\
\text { neighbors }\end{array}$ & Dummy & 0.43 & 0.26 & 0.17 & $* * *$ \\
\hline Support given to neighbors & Dummy & 0.51 & 0.36 & 0.15 & $* *$ \\
\hline $\begin{array}{l}\text { Support received from } \\
\text { neighbors }\end{array}$ & Number & 0.95 & 0.45 & 0.49 & $* * *$ \\
\hline Support given to neighbors & Number & 1.30 & 0.68 & 0.62 & $* * *$ \\
\hline
\end{tabular}

Source: Authors' calculations, radius 0.05 , version $1 . * * * / * * / * /(*)=$ Level of significance $>99 / 95 / 90 / 80 \%$.

\subsection{Further evidence on social life and living quality}

The cost-based analyses have been amended by looking at differences in the commitment to help neighbors, the use of time and daily routines, the various forms and numbers of activities which are performed within the neighborhood and the tradeoffs with other institutions within the same geographical district.

With regard to these questions which aim at picturing the residents' social life, our analysis generally yields positive effects for the treatment group as compared to the control group. Individuals in the treatment group spend significantly less time at home and take more often part in activities with their neighbors. These differences, however, should not be overrated because part of the individuals in the control group lives in single-family homes which may render the realization of joint activities with neighbors more difficult.

Furthermore, residents of the four housing projects use services offered by institutions which lie within the same district more often than the control group does. If we look at the tradeoffs between the housing projects and their surroundings, members of the treatment group attend public events in the respective district with a significantly higher frequency but also private institutions like restaurants, shops, or cinemas are frequented more often. Individuals with a need for inpatient care have been excluded from this part of the analysis.

Even the living conditions and the social cohesion in the respective districts have been rated more positively by members of the treatment group than by members of the control 
group. If we only look at individuals aged 50 years and above, these differences turn out to be even larger. This is mainly due to decreasing ratings by older individuals in the control group, whereas ratings by individuals in the treatment group are rather independent of age.

\section{Conclusion}

Earlier studies have already provided some evidence that housing projects promoting mutual support among neighbors induce higher housing satisfaction and improve their residents' quality of life. Our analysis adds to this literature by proving econometrically that these qualitative improvements can induce substantial socio-economic cost savings. The costs for supporting older residents in the new housing projects analyzed here are considerably lower than in alternative living situations. These differences can partly be traced to a better development of the residents' health status. However, they still exist - on a smaller scale -, if we control for differences in the health status. Cost differences become smaller if we exclude cases with a particularly high need of support. Nevertheless, even in this scenario, a tendency for cost advantages of the new housing projects based on mutual support is evident.

We can explain these cost differences partly by mutual support of neighbors which is promoted actively by community work in these housing projects as well as by their architectural infrastructure. Whether better health development and lower need of care in the new housing projects can be assigned to higher quality of social life and higher participation in social activities remains an open question, although many findings in prior studies on the relationship between health and social life point in this direction.

Even if this small and not representative sample does not allow for scaling up the results to a national level, we can expect substantial effects of similar projects on a broader scale. The socio-demographic composition of the residents in the SONG housing projects is not peculiar in any respect - not even with respect to prior voluntary engagement. With the usual scientific caution, we can eventually state that our analysis provides for the first time indicators for a substantial potential for cost savings in the support of elderly people in need of care. In the current institutional setting private households, social insurance and 
other public institutions providing financial support to elderly profit most from these cost savings. In the long run, however, it would be necessary to compensate the non-profit organizations that establish and run these projects for their additional expenses. 


\section{Bibliography}

Barker, J. C. (2002). "Neighbors, friends, and other nonkin caregivers of community-living dependent elders." The Journals of Gerontology. Series B, Psychological Sciences and Social Sciences 57(3): 158-167.

Burge, S., and D. Street. (2009). “Advantage and Choice: Social Relationships and Staff Assistance in Assisted Living." The Journals of Gerontology. Series B, Psychological Sciences and Social Sciences. Download:

http://psychsocgerontology.oxfordjournals.org/cgi/reprintsidebar/gbp118v1?\&frameset_url=htt $\mathrm{p} \% 3 \mathrm{~A} \% 2 \mathrm{~F} \% 2 \mathrm{Fpsychsocgerontology.oxfordjournals.org} \% 2 \mathrm{Fcgi} \% 2 \mathrm{Freprint} \% 2 \mathrm{Fgbp} 118 \mathrm{v} 1$ (January 29, 2010).

Caliendo, M. and S. Kopeinig (2005). „Some practical guidance for the implementation of propensity score matching." DIW-Discussion Paper 485.

Choi, J. S. (2004).” Evaluation of Community Planning and Life of Senior Cohousing Projects in Northern European Countries." European Planning Studies 12, no. 8 (Dec.): 1189-1216.

Christensen, D. L. et al. (1992). "Objective housing indicators as predictors of the subjective evaluations of elderly residents.” Journal of Environmental Psychology 12(3): 225-236.

Clark, W. A. V. and M. C. Deurloo (2006). "Aging in place and housing over-consumption." Journal of Housing and the Built Environment 21(3): 257-270.

Dehejia, R. H. and S. Wahba (2002): 'Propensity Score Matching Methods for Nonexperimental Causal Studies." The Review of Economics and Statistics 84(1), 151-161.

Dono, J. E. et al. (1979). "Primary Groups in Old Age: Structure and Function.” Research on Aging 1(4): 403-433.

Glass, A. P. (2009). "Aging in a Community of Mutual Support: The Emergence of an Elder Intentional Cohousing Community in the United States." Journal of Housing for the Elderly 23(4): 283.

Jenkins, K., Rahrig, A., Mehraban P. and A. L. Horgas. (2002). "Activity and Health-Related Quality of Life in Continuing Care Retirement Communities." Research on Aging 24(1): 124 149.

O'Bryant, S. L. (1985). "Neighbors' Support of Older Widows Who Live Alone in Their Own Homes." Gerontologist 25(3): 305-310.

Rantz, M. J. et al. (2008). “TigerPlace, A State-Academic-Private Project to Revolutionize Traditional Long-Term Care." Journal of Housing for the Elderly 22(1/2): 66-85. 
Roberts Enterprise Development Fund (RDF) (2000): SROI Methodology Paper. Download: www.redf.org (Feb. 26, 2010).

Rosenbaum, P. R. and D. B. Rubin. (1983). "The central role of the propensity score in observational studies for causal effects." Biometrika 70(1): 41-55.

Shippee, T. P. (2009). "But I Am Not Moving: Residents' Perspectives on Transitions Within a Continuing Care Retirement Community." Gerontologist 49(3): 418-427.

Chen, S.-L. et al. (2008). "Elders' Decisions to Enter Assisted Living Facilities: A Grounded Theory Study." Journal of Housing for the Elderly 22(1/2): 86-103.

Sianesi, B. (2004). “An Evaluation of the Active Labour Market Programmes in Sweden”. The Review of Economics and Statistics 86(1), 133-155.

Sikorska-Simmons, E. (2006). "The Effects of Organizational Policies on Resident Perceptions of Autonomy in Assisted Living." Journal of Housing for the Elderly 20(4): 61-77. 


\section{Appendix}

Tab. 10: Probit estimates for living in one of the SONG projects (total sample, version 1)

\begin{tabular}{|c|c|c|c|c|c|c|c|}
\hline Variable & Dimension & Coefficient & $\begin{array}{l}\text { Stand. } \\
\text { Dev. }\end{array}$ & z-Stat. & $\mathrm{P}>|\mathrm{z}|$ & \multicolumn{2}{|c|}{$\begin{array}{c}95 \% \\
\text { confidence } \\
\text { interval }\end{array}$} \\
\hline Age & Years & -0.002 & 0.00 & -0.53 & 0.60 & -0.01 & 0.00 \\
\hline Sex & Dummy & -0.063 & 0.13 & -0.48 & 0.63 & -0.32 & 0.19 \\
\hline Household size & $\begin{array}{l}\text { Number } \\
\text { Pers. }\end{array}$ & -0.079 & 0.07 & -1.06 & 0.29 & -0.23 & 0.07 \\
\hline Children & Number & 0.240 & 0.22 & 1.09 & 0.28 & -0.19 & 0.67 \\
\hline Income & Class 1-5 & -0.328 & 0.08 & -4.32 & 0.00 & -0.48 & -0.18 \\
\hline High qualification & Dummy & -0.813 & 0.16 & -5.2 & $\mathbf{0 . 0 0}$ & -1.12 & -0.51 \\
\hline Diseases before moving in & Number & 0.308 & 0.09 & 3.29 & $\mathbf{0 . 0 0}$ & 0.12 & 0.49 \\
\hline $\begin{array}{l}\text { Voluntary engagement } \\
\text { before moving in }\end{array}$ & Number & 0.009 & 0.12 & 0.07 & 0.94 & -0.23 & 0.25 \\
\hline Disabled & $\begin{array}{l}\text { Degree 0- } \\
100\end{array}$ & -0.003 & 0.00 & -1.33 & 0.19 & -0.01 & 0.00 \\
\hline Care level before moving in & Level 0-3 & -0.136 & 0.18 & -0.75 & 0.45 & -0.49 & 0.22 \\
\hline Nursing home & Dummy & 0.010 & 0.27 & 0.04 & 0.97 & -0.52 & 0.53 \\
\hline Assisted housing & Dummy & -0.626 & 0.18 & -3.45 & $\mathbf{0 . 0 0}$ & -0.98 & -0.27 \\
\hline Constant & & 1.127 & 0.34 & 3.28 & 0.00 & 0.45 & 1.80 \\
\hline Number of obs. & 554 & & & & & & \\
\hline Pseudo R2 & 0.1889 & & & & & & \\
\hline Log Likelihood & -295.25 & & & & & & \\
\hline LR (chi2) & 137.49 & & & & & & \\
\hline Prob $>$ chi 2 & 0 & & & & & & \\
\hline
\end{tabular}

Source: Authors' calculations. 
Tab. 11: Probit estimates for living in one of the SONG projects (sample 50+, version 1)

\begin{tabular}{|l|l|r|r|r|r|r|r|}
\hline Variable & Dimension & Coefficient & \multicolumn{1}{|c|}{$\begin{array}{c}\text { Stand. } \\
\text { Dev. }\end{array}$} & & z-Stat. & P $>|z|$ & \multicolumn{2}{|c|}{$\begin{array}{c}95 \% \\
\text { confidence } \\
\text { interval }\end{array}$} \\
\hline Age & Years & -0.009 & 0.01 & -1.06 & 0.29 & -0.02 & 0.01 \\
\hline Sex & Dummy & 0.194 & 0.18 & 1.07 & 0.29 & -0.16 & 0.55 \\
\hline Household size & $\begin{array}{l}\text { Number } \\
\text { Pers. }\end{array}$ & -0.272 & 0.16 & -1.66 & $\mathbf{0 . 1 0}$ & -0.59 & 0.05 \\
\hline Income & Class 1-5 & -0.518 & 0.10 & -5.08 & $\mathbf{0 . 0 0}$ & -0.72 & -0.32 \\
\hline High qualification & Dummy & -0.442 & 0.22 & -2 & $\mathbf{0 . 0 5}$ & -0.88 & -0.01 \\
\hline Diseases before moving in & Number & 0.118 & 0.16 & 0.74 & 0.46 & -0.19 & 0.43 \\
\hline Voluntary engagement \\
before moving in
\end{tabular}

Source: Authors' calculations. 
Tab. 12: Probit estimates for living in one of the SONG projects (total sample, version 2)

\begin{tabular}{|l|l|r|r|r|r|r|r|}
\hline Variable & Dimension & Coefficient & Stand. Dev. & Z-Stat. & $P>|z|$ & \multicolumn{2}{|c|}{$\begin{array}{c}95 \% \\
\text { confidence } \\
\text { interval }\end{array}$} \\
\hline Age & Years & -0.001 & 0.00 & -0.29 & 0.77 & -0.01 & 0.01 \\
\hline Sex & Dummy & -0.050 & 0.13 & -0.39 & 0.70 & -0.30 & 0.20 \\
\hline Household size & $\begin{array}{l}\text { Number } \\
\text { Pers. }\end{array}$ & -0.094 & 0.07 & -1.27 & 0.21 & -0.24 & 0.05 \\
\hline Children & Number & 0.232 & 0.22 & 1.05 & 0.29 & -0.20 & 0.66 \\
\hline Income & Class 1-5 & -0.309 & 0.08 & -4.11 & $\mathbf{0 . 0 0}$ & -0.46 & -0.16 \\
\hline High qualification & Dummy & -0.845 & 0.15 & -5.45 & $\mathbf{0 . 0 0}$ & -1.15 & -0.54 \\
\hline Diseases time of survey & Number & -0.003 & 0.12 & -0.02 & 0.98 & -0.24 & 0.24 \\
\hline Voluntary engagement \\
before moving in
\end{tabular}

Source: Authors' calculations. 
Tab. 13: Probit estimates for living in one of the SONG projects (sample 50+, version 2)

\begin{tabular}{|l|l|r|r|r|r|r|r|}
\hline Variable & Dimension & Coefficient & Stand. Dev. & z-Stat. & $P>|z|$ & \multicolumn{2}{|c|}{$\begin{array}{c}95 \% \\
\text { confidence } \\
\text { interval }\end{array}$} \\
\hline Age & Years & -0.009 & 0.01 & -1.07 & 0.29 & -0.02 & 0.01 \\
\hline Sex & Dummy & 0.228 & 0.18 & 1.27 & 0.21 & -0.12 & 0.58 \\
\hline Household size & $\begin{array}{l}\text { Number } \\
\text { Pers. }\end{array}$ & -0.314 & 0.16 & -1.93 & $\mathbf{0 . 0 5}$ & -0.63 & 0.00 \\
\hline Income & Class 1-5 & -0.487 & 0.10 & -4.89 & $\mathbf{0 . 0 0}$ & -0.68 & -0.29 \\
\hline High qualification & Dummy & -0.472 & 0.22 & -2.17 & $\mathbf{0 . 0 3}$ & -0.90 & -0.05 \\
\hline Diseases time of survey & Number & 0.084 & 0.16 & 0.53 & 0.59 & -0.22 & 0.39 \\
\hline Voluntary engagement \\
before moving in
\end{tabular}

Source: Authors' calculations. 
Tab. 14: Averages of selection variables (total sample, version 1)

\begin{tabular}{|c|c|c|c|c|c|c|c|}
\hline Variable & Dimension & Treatm. & Contr. & $\%$ Bias & $\begin{array}{l}\text { Red. } \\
\text { Bias }\end{array}$ & t-Stat. & $\mathrm{P}>|\mathrm{t}|$ \\
\hline \multirow[t]{2}{*}{ Age } & \multirow[t]{2}{*}{ Years } & 57.76 & 53.63 & 15.7 & & 1.78 & 0.08 \\
\hline & & 57.76 & 58.03 & -1 & 93.4 & -0.1 & 0.92 \\
\hline \multirow[t]{2}{*}{ Sex } & \multirow[t]{2}{*}{ Dummy } & 1.29 & 1.39 & -21.1 & & -2.37 & 0.02 \\
\hline & & 1.29 & 1.29 & -0.2 & 99.1 & -0.02 & 0.99 \\
\hline \multirow{2}{*}{$\begin{array}{l}\text { Diseases before } \\
\text { moving in }\end{array}$} & \multirow[t]{2}{*}{ Number } & 0.67 & 0.36 & 35.5 & & 4.14 & 0.00 \\
\hline & & 0.67 & 0.66 & 0 & 99.9 & 0 & 1.00 \\
\hline \multirow{2}{*}{$\begin{array}{l}\text { Voluntary } \\
\text { engagement } \\
\text { before moving in }\end{array}$} & \multirow[t]{2}{*}{ Number } & 0.51 & 0.61 & -20.3 & & -2.31 & 0.02 \\
\hline & & 0.51 & 0.53 & -3.3 & 83.6 & -0.33 & 0.74 \\
\hline \multirow[t]{2}{*}{ Disabled } & \multirow{2}{*}{$\begin{array}{l}\text { Level 0- } \\
100\end{array}$} & 19.70 & 15.21 & 13.40 & & 1.54 & 0.12 \\
\hline & & 19.70 & 20.89 & -3.6 & 73.6 & -0.34 & 0.74 \\
\hline \multirow{2}{*}{$\begin{array}{l}\text { Care level before } \\
\text { moving in }\end{array}$} & \multirow[t]{2}{*}{ Level 0-3 } & 0.13 & 0.07 & 15.30 & & 1.81 & 0.07 \\
\hline & & 0.13 & 0.14 & -1.40 & 91.1 & -0.12 & 0.90 \\
\hline \multirow[t]{2}{*}{ Household size } & \multirow{2}{*}{$\begin{array}{l}\text { Number } \\
\text { Persons }\end{array}$} & 1.81 & 2.32 & -40.3 & & -4.46 & 0.00 \\
\hline & & 1.81 & 1.70 & 8.9 & 77.8 & 1.01 & 0.31 \\
\hline \multirow[t]{2}{*}{ Children } & \multirow[t]{2}{*}{ Number } & 0.18 & 0.19 & -3.5 & & -0.39 & 0.69 \\
\hline & & 0.18 & 0.14 & 8.9 & -154.9 & 0.95 & 0.34 \\
\hline \multirow[t]{2}{*}{ Income } & \multirow[t]{2}{*}{ Class 1-5 } & 2.26 & 3.08 & -86.3 & & -9.41 & 0.00 \\
\hline & & 2.26 & 2.18 & 8.2 & 90.5 & 0.93 & 0.35 \\
\hline \multirow[t]{2}{*}{ Nursing home } & \multirow[t]{2}{*}{ Dummy } & 0.10 & 0.04 & 26.2 & & 3.16 & 0.00 \\
\hline & & 0.10 & 0.11 & -3.7 & 86 & -0.3 & 0.76 \\
\hline \multirow[t]{2}{*}{ Assisted housing } & \multirow[t]{2}{*}{ Dummy } & 0.17 & 0.20 & -6.2 & & -0.7 & 0.48 \\
\hline & & 0.17 & 0.23 & -14 & -124.9 & -1.37 & 0.17 \\
\hline \multirow[t]{2}{*}{ High qualification } & \multirow[t]{2}{*}{ Dummy } & 0.14 & 0.53 & -89 & & -9.66 & 0.00 \\
\hline & & 0.14 & 0.13 & 2.2 & 97.6 & 0.27 & 0.79 \\
\hline
\end{tabular}

Source: Authors' calculations, radius 0.05 . 
Tab. 15: Averages of selection variables (Sample 50+, version 1)

\begin{tabular}{|c|c|c|c|c|c|c|c|}
\hline Variable & Dimension & Treatm. & Contr. & $\%$ Bias & Red. Bias & t-Stat. & $\mathrm{P}>|\mathrm{t}|$ \\
\hline \multirow[t]{2}{*}{ Age } & \multirow[t]{2}{*}{ Years } & 74.58 & 73.07 & 13.7 & & 1.21 & 0.23 \\
\hline & & 75.11 & 75.93 & -7.5 & 45.4 & -0.62 & 0.54 \\
\hline \multirow[t]{2}{*}{ Sex } & \multirow[t]{2}{*}{ Dummy } & 1.27 & 1.32 & -10.4 & & -0.92 & 0.36 \\
\hline & & 1.27 & 1.24 & 6 & 42.1 & 0.51 & 0.61 \\
\hline \multirow{2}{*}{$\begin{array}{l}\text { Diseases before } \\
\text { moving in }\end{array}$} & \multirow[t]{2}{*}{ Number } & 0.88 & 0.60 & 29.7 & & 2.68 & 0.01 \\
\hline & & 0.85 & 0.98 & -13.4 & 54.9 & -1 & 0.32 \\
\hline \multirow{2}{*}{$\begin{array}{l}\text { Voluntary } \\
\text { engagement } \\
\text { before moving in }\end{array}$} & \multirow[t]{2}{*}{ Dummy } & 0.54 & 0.61 & -13.7 & & -1.23 & 0.22 \\
\hline & & 0.52 & 0.52 & 1.7 & 87.9 & 0.13 & 0.90 \\
\hline \multirow[t]{2}{*}{ Disabled } & \multirow{2}{*}{$\begin{array}{l}\text { Level 0- } \\
100\end{array}$} & 25.15 & 25.12 & 0.10 & & 0.01 & 1.00 \\
\hline & & 24.53 & 28.34 & -10.20 & -13322.30 & -0.80 & 0.42 \\
\hline \multirow{2}{*}{$\begin{array}{l}\text { Care level before } \\
\text { moving in }\end{array}$} & \multirow[t]{2}{*}{ Level 0-3 } & 0.14 & 0.11 & 7.50 & & 0.68 & 0.50 \\
\hline & & 0.14 & 0.19 & -11.9 & -58.8 & -0.87 & 0.39 \\
\hline \multirow[t]{2}{*}{ Household size } & \multirow{2}{*}{$\begin{array}{l}\text { Number } \\
\text { Persons }\end{array}$} & 1.26 & 1.59 & -54.9 & & -4.7 & 0.00 \\
\hline & & 1.27 & 1.22 & 6.7 & 87.7 & 0.7 & 0.48 \\
\hline \multirow[t]{2}{*}{ Income } & \multirow[t]{2}{*}{ Class $1-5$} & 2.11 & 2.97 & -91 & & -7.87 & 0.00 \\
\hline & & 2.15 & 2.11 & 4.6 & 94.9 & 0.43 & 0.67 \\
\hline \multirow[t]{2}{*}{ Nursing home } & \multirow[t]{2}{*}{ Dummy } & 0.16 & 0.06 & 30.4 & & 2.84 & 0.01 \\
\hline & & 0.16 & 0.22 & -16.7 & 45 & -1.06 & 0.29 \\
\hline \multirow[t]{2}{*}{ Assisted housing } & \multirow[t]{2}{*}{ Dummy } & 0.26 & 0.34 & -18 & & -1.6 & 0.11 \\
\hline & & 0.27 & 0.34 & -16.5 & 8.5 & -1.31 & 0.19 \\
\hline \multirow[t]{2}{*}{ High qualification } & \multirow[t]{2}{*}{ Dummy } & 0.13 & 0.37 & -57.8 & & -4.98 & 0.00 \\
\hline & & 0.13 & 0.14 & -1.90 & 96.7 & -0.19 & 0.85 \\
\hline
\end{tabular}

Source: Authors' calculations, radius 0.05 . 
Tab. 16: Averages of selection variables (total sample, version 2)

\begin{tabular}{|c|c|c|c|c|c|c|c|}
\hline Variable & Dimension & Treatm. & Contr. & $\%$ Bias & $\begin{array}{l}\text { Red. } \\
\text { Bias }\end{array}$ & t-Stat. & $\mathrm{P}>|\mathrm{t}|$ \\
\hline \multirow[t]{2}{*}{ Age } & \multirow[t]{2}{*}{ Years } & 57.76 & 53.63 & 15.7 & & 1.78 & 0.08 \\
\hline & & 57.76 & 58.26 & -1.9 & 87.9 & -0.19 & 0.85 \\
\hline \multirow[t]{2}{*}{ Sex } & \multirow[t]{2}{*}{ Dummy } & 1.29 & 1.39 & -21.1 & & -2.37 & 0.02 \\
\hline & & 1.29 & 1.30 & -2.2 & 89.5 & -0.23 & 0.82 \\
\hline \multirow{2}{*}{$\begin{array}{l}\text { Diseases time of } \\
\text { survey }\end{array}$} & \multirow[t]{2}{*}{ Number } & 1.03 & 0.86 & 13.5 & & 1.5 & 0.13 \\
\hline & & 1.03 & 1.20 & -12.4 & 8.6 & -1.18 & 0.24 \\
\hline \multirow{2}{*}{$\begin{array}{l}\text { Voluntary } \\
\text { engagement } \\
\text { before moving in }\end{array}$} & \multirow[t]{2}{*}{ Number } & 0.51 & 0.61 & -20.3 & & -2.31 & 0.02 \\
\hline & & 0.51 & 0.54 & -5.6 & 72.6 & -0.55 & 0.58 \\
\hline \multirow[t]{2}{*}{ Disabled } & \multirow{2}{*}{$\begin{array}{l}\text { Level 0- } \\
100\end{array}$} & 19.70 & 15.21 & 13.40 & & 1.54 & 0.12 \\
\hline & & 19.70 & 20.79 & -3.2 & 75.9 & -0.31 & 0.76 \\
\hline \multirow{2}{*}{$\begin{array}{l}\text { Care level time of } \\
\text { survey }\end{array}$} & \multirow[t]{2}{*}{ Level 0-3 } & 0.19 & 0.16 & 6.1 & & 0.7 & 0.49 \\
\hline & & 0.19 & 0.22 & -6.7 & -10.6 & -0.65 & 0.51 \\
\hline \multirow[t]{2}{*}{ Household size } & \multirow{2}{*}{$\begin{array}{l}\text { Number } \\
\text { Persons }\end{array}$} & 1.81 & 2.32 & -40.3 & & -4.46 & 0.00 \\
\hline & & 1.81 & 1.74 & 5.8 & 85.7 & 0.63 & 0.53 \\
\hline \multirow[t]{2}{*}{ Children } & \multirow[t]{2}{*}{ Number } & 0.18 & 0.19 & -3.5 & & -0.39 & 0.69 \\
\hline & & 0.18 & 0.15 & 7.7 & -119.4 & 0.81 & 0.42 \\
\hline \multirow[t]{2}{*}{ Income } & \multirow[t]{2}{*}{ Class 1-5 } & 2.26 & 3.08 & -86.3 & & -9.41 & 0.00 \\
\hline & & 2.26 & 2.19 & 6.4 & 92.5 & 0.73 & 0.46 \\
\hline \multirow[t]{2}{*}{ Nursing home } & \multirow[t]{2}{*}{ Dummy } & 0.10 & 0.04 & 26.2 & & 3.16 & 0.00 \\
\hline & & 0.10 & 0.10 & -0.1 & 99.5 & -0.01 & 0.99 \\
\hline \multirow[t]{2}{*}{ Assisted housing } & \multirow[t]{2}{*}{ Dummy } & 0.17 & 0.20 & -6.2 & & -0.7 & 0.48 \\
\hline & & 0.17 & 0.21 & -8.9 & -42.6 & -0.88 & 0.38 \\
\hline \multirow[t]{2}{*}{ High qualification } & \multirow[t]{2}{*}{ Dummy } & 0.14 & 0.53 & -89 & & -9.66 & 0.00 \\
\hline & & 0.14 & 0.14 & 0.1 & 99.8 & 0.02 & 0.99 \\
\hline
\end{tabular}

Source: Authors' calculations, radius 0.05 . 
Tab. 17: Averages of selection variables (sample 50+, version 2)

\begin{tabular}{|c|c|c|c|c|c|c|c|}
\hline Variable & Dimension & Treatm. & Contr. & $\%$ Bias & $\begin{array}{l}\text { Red. } \\
\text { Bias }\end{array}$ & t-Stat. & $\mathrm{P}>|\mathrm{t}|$ \\
\hline \multirow[t]{2}{*}{ Age } & \multirow[t]{2}{*}{ Years } & 74.58 & 73.07 & 13.7 & & 1.21 & 0.23 \\
\hline & & 74.58 & 75.41 & -7.60 & 44.6 & -0.63 & 0.53 \\
\hline \multirow[t]{2}{*}{ Sex } & \multirow[t]{2}{*}{ Dummy } & 1.27 & 1.32 & -10.4 & & -0.92 & 0.36 \\
\hline & & 1.27 & 1.28 & -1.00 & 90.5 & -0.08 & 0.94 \\
\hline \multirow{2}{*}{$\begin{array}{l}\text { Diseases time of } \\
\text { survey }\end{array}$} & \multirow[t]{2}{*}{ Number } & 1.38 & 1.35 & 1.8 & & 0.16 & 0.88 \\
\hline & & 1.38 & 1.55 & -12.40 & -590.5 & -1.01 & 0.32 \\
\hline \multirow{2}{*}{$\begin{array}{l}\text { Voluntary } \\
\text { engagement } \\
\text { before moving in }\end{array}$} & \multirow[t]{2}{*}{ Dummy } & 0.54 & 0.61 & -13.7 & & -1.23 & 0.22 \\
\hline & & 0.54 & 0.55 & -2.80 & 79.3 & -0.23 & 0.82 \\
\hline \multirow[t]{2}{*}{ Disabled } & \multirow{2}{*}{$\begin{array}{l}\text { Level 0- } \\
100\end{array}$} & 25.15 & 25.12 & 0.10 & & 0.01 & 1.00 \\
\hline & & 25.15 & 27.79 & -7.00 & -9207.5 & -0.56 & 0.58 \\
\hline \multirow{2}{*}{$\begin{array}{l}\text { Care level time of } \\
\text { survey }\end{array}$} & \multirow[t]{2}{*}{ Level 0-3 } & 0.23 & 0.26 & -5.1 & & -0.45 & 0.65 \\
\hline & & 0.23 & 0.29 & -10.60 & -109.8 & -0.89 & 0.38 \\
\hline \multirow[t]{2}{*}{ Household size } & \multirow{2}{*}{$\begin{array}{l}\text { Number } \\
\text { Persons }\end{array}$} & 1.26 & 1.59 & -54.9 & & -4.7 & 0.00 \\
\hline & & 1.26 & 1.28 & -3.70 & 93.2 & -0.38 & 0.71 \\
\hline \multirow[t]{2}{*}{ Income } & \multirow[t]{2}{*}{ Class 1-5 } & 2.11 & 2.97 & -91 & & -7.87 & 0.00 \\
\hline & & 2.11 & 2.24 & -13.00 & 85.7 & -1.16 & 0.25 \\
\hline \multirow[t]{2}{*}{ Nursing home } & \multirow[t]{2}{*}{ Dummy } & 0.16 & 0.06 & 30.4 & & 2.84 & 0.01 \\
\hline & & 0.16 & 0.16 & 0.70 & 97.6 & 0.05 & 0.96 \\
\hline \multirow[t]{2}{*}{ Assisted housing } & \multirow[t]{2}{*}{ Dummy } & 0.26 & 0.34 & -18 & & -1.6 & 0.11 \\
\hline & & 0.26 & 0.33 & -15.70 & 12.9 & -1.28 & 0.20 \\
\hline \multirow[t]{2}{*}{ High qualification } & \multirow[t]{2}{*}{ Dummy } & 0.13 & 0.37 & -57.8 & & -4.98 & 0.00 \\
\hline & & 0.13 & 0.17 & -10.2 & 82.4 & -0.96 & 0.34 \\
\hline
\end{tabular}

Source: Authors' calculations, radius 0.2. 
Tab. 18: ATT Costs of assistance and support in daily life (total sample, version 1)

\begin{tabular}{|l|l|r|r|r|r|}
\hline Variable & Dimension & Treat. & Contr. & Diff. & Significance \\
\hline Costs (self-covered, reported) & Euro/Month & 34.58 & 56.43 & -21.85 & \\
\hline Costs (self-covered, imputed) & Euro/Month & 126.19 & 257.67 & -131.48 & $* *$ \\
\hline Total Costs & Euro/Month & 245.09 & 354.55 & -109.46 & $*$ \\
\hline
\end{tabular}

Source: Authors' calculations, radius 0.05, version $1 . * * * / * * / * /(*)=$ Level of significance $>99 / 95 / 90 / 80 \%$.

\section{Tab. 19: ATT Costs of assistance and support in daily life (sample 50+,} version 1)

\begin{tabular}{|l|l|r|r|r|r|}
\hline Variable & Dimension & Treatm. & Contr. & Diff. & Significance \\
\hline Costs (self-covered, reported) & Euro/Month & 25.14 & 41.71 & -16.58 & $(*)$ \\
\hline Costs (self-covered, imputed) & Euro/Month & 132.71 & 381.79 & -249.08 & $* * *$ \\
\hline Total Costs & Euro/Month & 268.22 & 537.56 & -269.35 & $* * *$ \\
\hline
\end{tabular}

Source: Authors' calculations, radius 0.05 , version $1 . * * * / * * / * /(*)=$ Level of significance $>99 / 95 / 90 / 80 \%$.

\section{Tab. 20: ATT Costs of assistance and support in daily life (total sample, version 2)}

\begin{tabular}{|l|l|r|r|r|r|}
\hline Variable & Dimension & Treatm. & Contr. & Diff. & Significance \\
\hline Costs (self-covered, reported) & Euro/Month & 34.58 & 50.30 & -15.72 & \\
\hline Costs (self-covered, imputed) & Euro/Month & 126.19 & 221.36 & -95.17 & \\
\hline Total Costs & Euro/Month & 245.09 & 308.68 & -63.59 & \\
\hline
\end{tabular}

Source: Authors' calculations, radius 0.05, version $1 . * * * / * * / * /(*)=$ Level of significance $>99 / 95 / 90 / 80 \%$. 
Tab. 21: ATT Costs of assistance and support in daily life (sample 50+, version 2)

\begin{tabular}{|l|l|r|r|r|r|}
\hline Variable & Dimension & Treatm. & Contr. & Diff. & Significance \\
\hline Costs (self-covered, reported) & Euro/Month & 24.38 & 35.06 & -10.68 & \\
\hline Costs (self-covered, imputed) & Euro/Month & 132.80 & 281.31 & -148.51 & $* *$ \\
\hline Total Costs & Euro/Month & 270.02 & 421.92 & -151.91 & $* * *$ \\
\hline
\end{tabular}

Source: Authors' calculations, radius 0.2 , version $1 . * * * / * * / * /(*)=$ Level of significance $>99 / 95 / 90 / 80 \%$.

Tab. 22: ATT Costs of assistance and support in daily life (total sample, version 1), without nursing home residents

\begin{tabular}{|l|l|r|r|r|r|}
\hline Variable & Dimension & Treatm. & Contr. & Diff. & Significance \\
\hline Costs (self-covered, reported) & Euro/Month & 36.46 & 62.88 & -26.42 & \\
\hline Costs (self-covered, imputed) & Euro/Month & 91.07 & 137.71 & -46.64 & \\
\hline Total costs & Euro/Month & 204.59 & 214.77 & -10.18 & \\
\hline
\end{tabular}

Source: Authors' calculations, radius $0.05, * * * / * * / * /(*)=$ Level of significance $>99 / 95 / 90 / 80 \%$.

Tab. 23: ATT Costs of assistance and support in daily life (sample 50+, version 1), without nursing home residents

\begin{tabular}{|l|l|r|r|r|r|}
\hline Variable & Dimension & Treatm. & Contr. & Diff. & Significance \\
\hline Costs (self-covered, reported) & Euro/Month & 26.26 & 48.10 & -21.84 & $\left(^{*}\right)$ \\
\hline Costs (self-covered, imputed) & Euro/Month & 74.41 & 151.50 & -77.09 & $* *$ \\
\hline Total costs & Euro/Month & 203.39 & 273.88 & -70.49 & $\left(^{*}\right)$ \\
\hline
\end{tabular}

Source: Authors' calculations, radius $0.05, * * * / * * / * /(*)=$ Level of significance $>99 / 95 / 90 / 80 \%$. 
Tab. 24: ATT Costs of assistance and support in daily life (total sample, version 2), without nursing home residents

\begin{tabular}{|l|l|r|r|r|l|}
\hline Variable & Dimension & Treatm. & Contr. & Diff. & Significance \\
\hline Costs (self-covered, reported) & Euro/Month & 36.32 & 59.02 & -22.71 & \\
\hline Costs (self-covered, imputed) & Euro/Month & 90.62 & 113.02 & -22.40 & \\
\hline Total costs & Euro/Month & 203.86 & 185.67 & 18.19 & \\
\hline
\end{tabular}

Source: Authors' calculations, radius $0.05, * * * / * * / * /\left(^{*}\right)=$ Level of significance $>99 / 95 / 90 / 80 \%$.

Tab. 25: ATT Costs of assistance and support in daily life (sample 50+, version 2), without nursing home residents

\begin{tabular}{|l|l|r|r|r|r|}
\hline Variable & Dimension & Treatm. & Contr. & Diff. & Significance \\
\hline Costs (self-covered, reported) & Euro/Month & 25.29 & 41.44 & -16.15 & $(*)$ \\
\hline Costs (self-covered, imputed) & Euro/Month & 75.73 & 111.25 & -35.52 & \\
\hline Total costs & Euro/Month & 207.13 & 236.09 & -28.96 & \\
\hline
\end{tabular}

Source: Authors' calculations, radius $0.2, * * * * * / * /(*)=$ Level of significance $>99 / 95 / 90 / 80 \%$.

Tab. 26: Comparison of observations

\begin{tabular}{|l|c|c|c|c|}
\hline & \multicolumn{2}{|c|}{ Total } & without nursing home residents \\
\hline & Treatm. & Contr. & Treatm. & Contr. \\
\hline Version 1 & & & & \\
\hline Total & 203 & 351 & 181 & 338 \\
\hline $50+$ & 128 & 203 & 105 & 190 \\
\hline Version 2 & 203 & 351 & 182 & 338 \\
\hline Total & 132 & 203 & 111 & 190 \\
\hline $50+$ & & & & \\
\hline
\end{tabular}

Source: Authors' calculations. 
Tab. 27: ATT Mutual neighborly support (total sample)

\begin{tabular}{|c|c|c|c|c|c|}
\hline & Dimension & Treatm. & Contr. & Diff. & Significance \\
\hline Support from neighbors received & Dummy & 0.37 & 0.32 & 0.05 & \\
\hline Support to neighbors given & Dummy & 0.51 & 0.34 & 0.17 & $* * *$ \\
\hline Support from neighbors received & Number & 0.76 & 0.55 & 0.21 & $*$ \\
\hline Support to neighbors given & Number & 1.37 & 0.67 & 0.69 & $* * *$ \\
\hline \multicolumn{6}{|l|}{ Support received } \\
\hline Shopping & Dummy & 0.15 & 0.11 & 0.04 & $(*)$ \\
\hline Housekeeping & Dummy & 0.08 & 0.06 & 0.02 & \\
\hline Garden/balcony & Dummy & 0.06 & 0.05 & 0.01 & \\
\hline Janitor/Crafting & Dummy & 0.15 & 0.05 & 0.10 & $* * *$ \\
\hline Taking care of children & Dummy & 0.03 & 0.03 & 0.00 & \\
\hline Security & Dummy & 0.06 & 0.05 & 0.02 & \\
\hline Writing/reading & Dummy & 0.01 & 0.00 & 0.01 & \\
\hline Attending local authorities, post office, doctors & Dummy & 0.05 & 0.00 & 0.05 & $* * *$ \\
\hline Consolation/talk & Dummy & 0.13 & 0.12 & 0.01 & \\
\hline Medical Care & Dummy & 0.00 & 0.00 & 0.00 & \\
\hline Other & Dummy & 0.02 & 0.09 & -0.07 & $* * *$ \\
\hline \multicolumn{6}{|l|}{ Support given } \\
\hline Shopping & Dummy & 0.31 & 0.11 & 0.20 & $* * *$ \\
\hline Housekeeping & Dummy & 0.10 & 0.05 & 0.05 & * \\
\hline Garden/balcony & Dummy & 0.13 & 0.06 & 0.07 & $* *$ \\
\hline Janitor/Crafting & Dummy & 0.09 & 0.06 & 0.03 & \\
\hline Taking care of children & Dummy & 0.06 & 0.05 & 0.02 & \\
\hline Security & Dummy & 0.13 & 0.02 & 0.11 & $* * *$ \\
\hline Writing/reading & Dummy & 0.08 & 0.01 & 0.08 & $* * *$ \\
\hline Attending local authorities, post office, doctors & Dummy & 0.14 & 0.01 & 0.13 & $* * *$ \\
\hline Consolation/talk & Dummy & 0.25 & 0.18 & 0.07 & * \\
\hline Medical Care & Dummy & 0.00 & 0.02 & -0.02 & \\
\hline Other & Dummy & 0.07 & 0.11 & -0.04 & $(*)$ \\
\hline
\end{tabular}

Source: Authors' calculations, radius 0.05 , version $1 . * * * / * * / * /(*)=$ Level of significance $>99 / 95 / 90 / 80 \%$. 
Tab. 28: ATT Mutual neighborly support (sample 50+)

\begin{tabular}{|c|c|c|c|c|c|}
\hline & Dimension & Treatm. & Contr. & Diff. & Significance \\
\hline Support from neighbors received & Dummy & 0.43 & 0.26 & 0.17 & $* * *$ \\
\hline Support to neighbors given & Dummy & 0.51 & 0.36 & 0.15 & $* *$ \\
\hline Support from neighbors received & Number & 0.95 & 0.45 & 0.49 & $* * *$ \\
\hline Support to neighbors given & Number & 1.30 & 0.68 & 0.62 & $* * *$ \\
\hline \multicolumn{6}{|l|}{ Support received } \\
\hline Shopping & Dummy & 0.20 & 0.09 & 0.11 & $* *$ \\
\hline Housekeeping & Dummy & 0.11 & 0.04 & 0.07 & * \\
\hline Garden/balcony & Dummy & 0.08 & 0.04 & 0.03 & $(*)$ \\
\hline Janitor/Crafting & Dummy & 0.18 & 0.04 & 0.14 & $* * *$ \\
\hline Taking care of children & Dummy & 0.00 & 0.00 & 0.00 & \\
\hline Security & Dummy & 0.09 & 0.02 & 0.07 & $* *$ \\
\hline Writing/reading & Dummy & 0.02 & 0.00 & 0.01 & \\
\hline Attending local authorities, post office, doctors & Dummy & 0.08 & 0.00 & 0.07 & $* * *$ \\
\hline Consolation/talk & Dummy & 0.16 & 0.15 & 0.01 & \\
\hline Medical Care & Dummy & 0.01 & 0.00 & 0.00 & \\
\hline Other & Dummy & 0.03 & 0.06 & -0.03 & \\
\hline \multicolumn{6}{|l|}{ Support given } \\
\hline Shopping & Dummy & 0.32 & 0.11 & 0.21 & $* * *$ \\
\hline Housekeeping & Dummy & 0.06 & 0.04 & 0.02 & \\
\hline Garden/balcony & Dummy & 0.10 & 0.05 & 0.05 & $(*)$ \\
\hline Janitor/Crafting & Dummy & 0.09 & 0.04 & 0.04 & \\
\hline Taking care of children & Dummy & 0.05 & 0.04 & 0.01 & \\
\hline Security & Dummy & 0.13 & 0.02 & 0.12 & $* * *$ \\
\hline Writing/reading & Dummy & 0.09 & 0.01 & 0.07 & $* *$ \\
\hline Attending local authorities, post office, doctors & Dummy & 0.15 & 0.02 & 0.13 & $* * *$ \\
\hline Consolation/talk & Dummy & 0.25 & 0.24 & 0.01 & \\
\hline Medical Care & Dummy & 0.00 & 0.02 & -0.02 & $(*)$ \\
\hline Other & Dummy & 0.06 & 0.09 & -0.03 & \\
\hline
\end{tabular}

Source: Authors' calculations, radius 0.05 , version $1 . * * * / * * / * /(*)=$ Level of significance $>99 / 95 / 90 / 80 \%$. 